\title{
Biostratigraphical and palaeobiogeographical implications of Lower Silurian Radiolaria from black cherts of the Armorican Massif (France)
}

\author{
MARTIN TETARD ${ }^{1 *}$, TANIEL DANELIAN ${ }^{1} \&$ PAULA NOBLE $^{1,2}$ \\ ${ }^{1}$ University of Lille 1, Géosystèmes (UMR CNRS 8217), Cité Scientifique, SN5, 59655 Villeneuve d'Ascq cedex, France \\ ${ }^{2}$ University of Nevada Reno, Department of Geological Sciences, Mackay School of Mines, Reno, NV 89557-0138, USA \\ *Corresponding author (e-mail: martin.tetard@etudiant.univ-lille1.fr)
}

\begin{abstract}
A moderately well-preserved radiolarian assemblage was recovered from organic-rich black chert in a Llandovery (Lower Silurian) sequence that crops out in southern Brittany (Chalonnes-sur-Loire section, Armorican Massif, France). The assemblage is composed of two families (Rotasphaeridae and Haplotaeniatidae), four genera (?Diparvapila, Secuicollacta, Orbiculopylorum, Haplotaeniatum) and 13 species. Some were identified from whole specimens preserved in silica and extracted following dilute hydrofluoric acid processing, while others were recognized in thin-section preparations, as they are beautifully preserved as 'carbonized' microfossils. The age range suggested by conodonts and chitinozoans yielded after HF processing from one of the 27 studied samples is in good agreement with the previously published age based on graptolites. The recovered radiolarians are discussed, documented and compared with known Rhuddanian, Aeronian and lower Telychian assemblages in the literature. The stratigraphic ranges are extended for the species Secuicollacta bipola, S. hexactinia, S. parvitesta, Orbiculopylorum granti and O. splendens based on our new data. A significant number of radiolarians found in our samples occur in Llandovery sections from Alaska, Nevada, Arctic Canada and Sweden. These similarities are used to discuss the palaeodistribution of Lower Silurian Radiolaria and our observations support the hypothesis of a wide geographical distribution for these Palaeozoic species.
\end{abstract}

KEYWORDS: Radiolaria, Silurian, biostratigraphy, plankton palaeobiogeography, Armorican Massif

\section{INTRODUCTION}

Modern polycystine Radiolaria are widely distributed in all oceans. Their fossil record extends back to the Lower Cambrian (Pouille et al., 2011; Korovnikov et al., 2013) and provides a proxy to probe the biotic response of planktic heterotrophic microorganisms to global environmental changes that took place during the Phanerozoic. In spite of their important potential, our present knowledge of Lower Palaeozoic radiolarian faunas is still fragmentary (Maletz, 2011), especially for the high palaeolatitudinal regions (Danelian et al., 2013).

This holds also true for the Lower Silurian, as only few Llandovery radiolarian studies are published, such as the papers by Noble et al. (1997, 1998) for Nevada, MacDonald (1998, 2004, 2006a) for the Canadian Arctic, Won et al. (2002) for Alaska, Noble \& Maletz (2000) and Umeda \& Suzuki (2005) for Sweden, Noble et al. (1998) for Germany and Kurihara \& Sashida (2000) for Japan. It is likely that Lower Silurian radiolarians were widely distributed and therefore they can be very useful for global biostratigraphic correlation (e.g. Noble \& Aitchison, 2000 or MacDonald, 2006b). Noble \& Aitchison (2000) tried to use the First Appearance Datum (FAD) and Last Appearance Datum (LAD) of several taxa in order to improve Lower Silurian radiolarian biozonation. However, significant parts of the Llandovery are still very poorly known due to the paucity of radiolarian records (i.e. the Rhuddanian and the Aeronian), not to mention the absence of radiolarian data from high latitudes.

We have recently extracted radiolarians from Lower Silurian organic-rich cherts that crop out in southern Brittany (France). In a preliminary account (Tetard et al., 2014) we stressed mainly the geological, palaeogeographical and palaeoenvironmental setting of the studied sequence. The focus of this paper lies in the detailed taxonomic discussion and documentation of the entire fauna recovered so far and its comparison with other Llandovery radiolarian assemblages known worldwide. The palaeogeographical position of the studied locality is advantageous because it was situated in middle to high palaeolatitudes and provides the opportunity to discuss the distribution of Lower Silurian radiolarian assemblages in the context of palaeogeographical position and of palaeoceanic circulation patterns.

\section{GEOLOGICAL AND STRATIGRAPHIC SETTINGS}

The Armorican Massif is composed of several Proterozoic and Lower Palaeozoic domains, deformed during the Variscan Orogeny and separated by major shear zones (Fig. 1a; Ballèvre et al., 2009). Among these structures, the Ligerian domain is separated from the Central Armorican domain by the Northern South Armorican Shear Zone (SASZ) and limited to the south by a branch of the Southern SASZ. The studied section is located in the Ancenis unit of the Ligerian domain and composed of isolated Silurian sequences of 'phtanites' unreported in other domains (Piçarra et al., 2002). Nowadays, these 'phtanites' are considered to be argillaceous black cherts, rich in silica and organic matter causing its black coloration (Dabard, 2000). This succession is likely to have been deposited over a distal slope along the northern continental margin of Gondwana (Piçarra et al., 2009). For further details about the geological and palaeogeographical settings, the reader is referred to Tetard et al. (2014).

The outcrop of the studied 'Chalonnes-sur-Loire' section (Fig. 1; WGS84 coordinates: 47²0'44.29"N, $0^{\circ} 45^{\prime} 35.83^{\prime \prime} \mathrm{W}$ ) displays an isolated Silurian sequence of argillaceous and carbonaceous black chert, unknown from other areas of the 


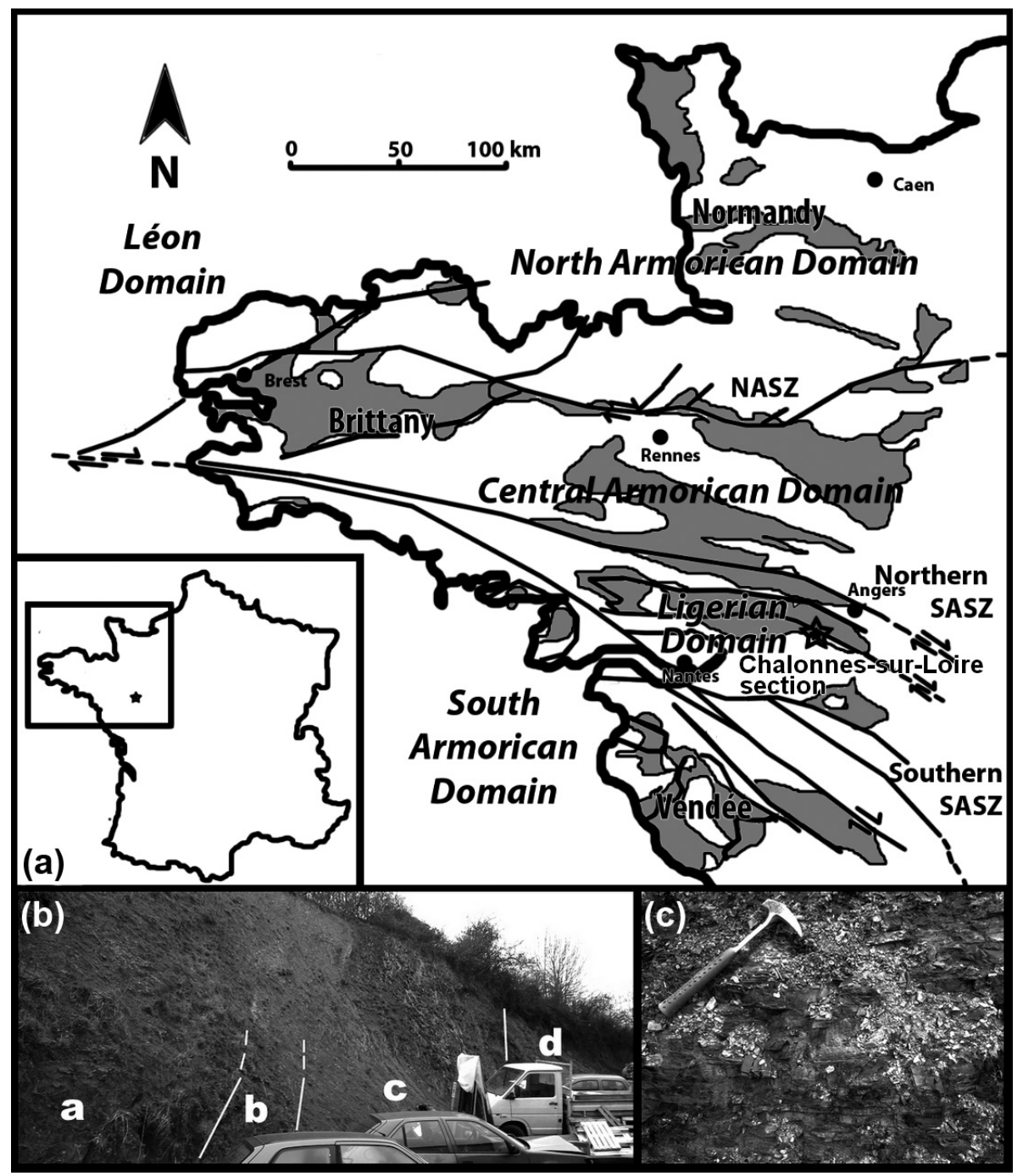

Fig. 1. (a) Distribution of Palaeozoic basement (grey areas), main tectonic features and location of the studied outcrop (star) of the Armorican Massif. (b) Photograph of the 'Chalonnes-sur-Loire' outcrop, displaying intervals 'a' (diamictite), 'b' (grey shale), 'c' (black chert and shale) and 'd' (deformed horizon). (c) Close-up picture of the 'phtanite' levels.

Armorican Massif (Piçarra et al., 2002). This succession was previously dated in detail by the presence of abundant graptolites throughout the sequence (Piçarra et al., 2002). The section exhibits in its northeastern part a $c .30 \mathrm{~m}$ thick succession of uppermost Ordovician diamictite (interval 'a' on Figs 1 and 2), followed by c. $2 \mathrm{~m}$ thick grey shale (interval 'b'), accumulated respectively during the Hirnantian glaciation and the subsequent deglacial period. Then, $c$. $10 \mathrm{~m}$ of 'phtanite' (cm- to dm-thick black bedded chert rich in organic matter, interbedded with black shale containing pyrite) corresponding to the interval 'c' overlie conformably the grey siltstone and shale (Piçarra et al., 2009). This interval represents the most complete Llandovery succession of the Ligerian domain, recording a continuous sedimentation during the Rhuddanian and the Aeronian, as testified by its graptolitic and chitinozoan content (Piçarra et al., 2009). Interval ' $d$ ' corresponds to strata displaying deformed horizons, difficult to access (Piçarra et al., 2002, 2009).

\section{MATERIAL AND METHODS}

Twenty-seven samples were collected at regular intervals (and depending on the accessibility of the outcrop) all along the 'c' interval of the studied sequence, corresponding to the interval of black chert and shale, from the base of the Rhuddanian to the upper Aeronian. Samples containing radiolarians were first selected under a polarizing microscope based on $30 \mu \mathrm{m}$-thick thinsection observations. Moreover, the mineralogy of some samples was confirmed by using RAMAN spectroscopy (Jobin Yvon, LabRam HR 800UV).

Promising samples selected for laboratory processing were chemically treated as follows: samples were first washed, rinsed with distilled water, oven-dried, crushed into smaller fragments and then soaked in numbered plastic beakers containing diluted (4.8\%) HF for $24 \mathrm{~h}$. Then, the fragments were sieved with $63 \mu \mathrm{m}$ and $630 \mu \mathrm{m}$ sieves and rinsed. Fragments larger than $630 \mu \mathrm{m}$ were soaked again in renewed $4.8 \% \mathrm{HF}$ for $24 \mathrm{~h}$, while the fraction 

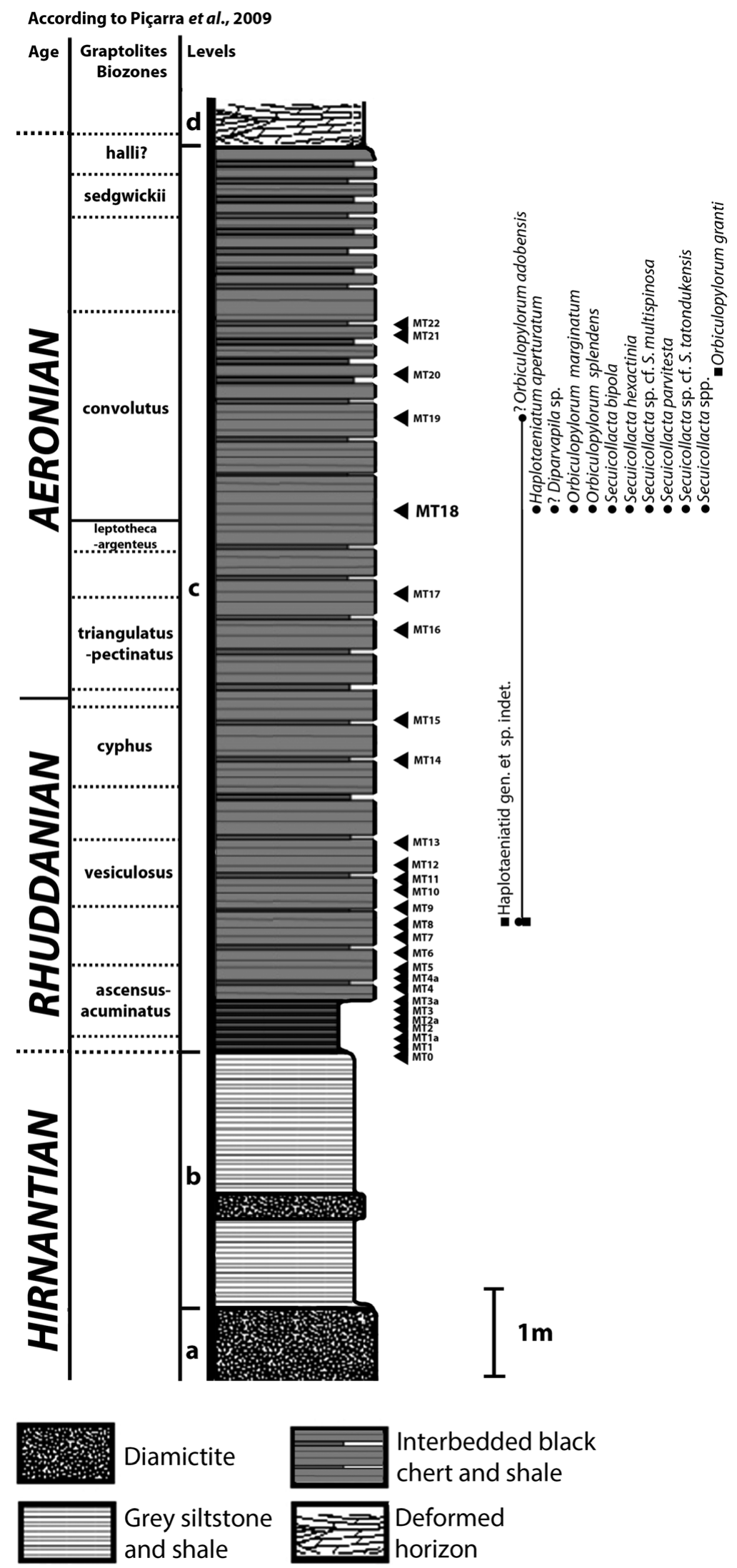

Fig. 2. Lithostratigraphy of the studied Chalonnes-sur-Loire outcrop, including the graptolite biozones identified by Piçarra et al. (2009) and the stratigraphic position of the radiolarian-bearing samples MT8, MT18, MT19 and MT20 (circles and squares represent SEM and thin section identifications, respectively). 
comprised between $63 \mu \mathrm{m}$ and $630 \mu \mathrm{m}$ was filtered and dried for microscopic examination. This procedure was repeated six times. Residues were examined under a binocular microscope and radiolarians were picked, mounted on carbon stubs, metal coated, scanned and magnified with a scanning electron microscope (SEM; FEI, Quanta 200).

\section{RESULTS}

\section{Petrography}

In thin sections, we observed two different sedimentary textures; one exhibiting numerous chalcedonic spheres, 200-300 $\mu \mathrm{m}$ in diameter, which are probably very poorly preserved 'radiolarian remains', as mentioned by Piçarra et al. (2009), alternating with a second texture devoid of any spheres. These textures are interpreted to represent alternating radiolarian-rich and radiolarianpoor microfacies. However, both microfacies also exhibit thin laminations rich in quartz silt with a clayey matrix. Samples are also rich in organic matter (matrix as well as some radiolarians) and contain rhombic pyrite crystals. Occasionally, a chalcedonic sphere might contain well-preserved remains of Radiolaria (Tetard et al., 2014, fig. 3.9) that can be identified in thin section (found in samples MT1, MT8, MT18, MT19, MT20). Those well-preserved radiolarians, as well as several others extracted and observed with a SEM (MT8, MT19) seem to be carbonized (RAMAN spectra), such as the Saxothuringian fauna reported by Noble et al. (1998).

\section{Radiolarians}

The best preserved radiolarians (Pls 1 and 2) come from the sample MT18 which corresponds to a jasper bed. In addition to radiolarians, some conodonts, chitinozoans and sponge spicules were also extracted and picked from the residue recovered from this sample MT18 (Pl. 2). Several radiolarians, although less well-preserved, were also recovered from other samples (e.g. c. 15 specimens from sample MT8, a few others from samples MT19 and MT20). Only the best specimens (i.e. around 150, 6 and 5, respectively, for samples MT18, MT19 and MT8) were mounted on carbon stubs for SEM observation. Regrettably only a fraction of them were identifiable (i.e. around 60 specimens from sample MT18, 2 specimens from MT8 and only one from MT19), a problem attributed to preservation. Some radiolarians were identified based on thin-section observations (samples MT8, MT18 and MT20; P1. 3).

The recovered assemblage is composed of archaeospicularian Radiolaria belonging to the family Rotasphaeridae (Secuicollacta bipola Won et al., 2002, S. hexactinia Won et al., 2002, S. sp. cf. S. multispinosa Won et al., 2002, S. parvitesta Won et al., 2002, $S$. sp. cf. S. tatondukensis Won et al., 2002, Secuicollacta spp. and ?Diparvapila sp.) and to the spumellarian family Haplotaeniatidae (Haplotaeniatum aperturatum Noble et al., 1998, Orbiculopylorum marginatum Noble et al., 1998 and O. splendens Noble et al., 1998) for sample MT18. Among the radiolarians recovered from samples MT8, MT19 and MT20, only spumellarian haplotaeniatids were identified. More particularly, a few specimens of ?O. adobensis Noble et al., 1998 were identified in samples MT8 and MT19, and one specimen was identified as Orbiculopylorum granti MacDonald, 2006, in sample MT20. The occurrence of identified taxa is summarized in Figure 2.

\section{Conodonts and chitinozoans}

Four species of chitinozoans were recovered from sample MT18 (Conochitina ?edjelensis Taugourdeau, 1963, Conochitina ?iklaensis Nestor 1980, Cyathochitina ?campanulaeformis Eisenack, 1931 and Spinachitina ?maennili Nestor, 1980), as well as two species of conodonts (Distomodus staurognathoides Walliser, 1964, Walliserodus curvatus Branson \& Branson, 1947) and sponge spicules ( $\mathrm{Pl}$. 2). The species identification of the chitinozoans is doubtful due to a poor preservation. The taxon ranges of these different species of conodonts (Kleffner, 1987; Zhang \& Barnes, 2002; Hints et al., 2006) and chitinozoans (Loydell et al., 2003, 2010; Ghavidel-syooki, 2006; Ghavidel-syooki \& Vecoli, 2007; Butcher, 2009; Nestor, 2012) is provided in Figure 3.

\section{SYSTEMATIC PALAEONTOLOGY}

Subclass Radiolaria Müller, 1858

Superorder Polycystina Ehrenberg, 1838; emend. Riedel, 1967 Order Archaeospicularia Dumitrica, Caridroit \& De Wever, 2000

Family Rotasphaeridae Noble, 1994; emend. Noble \& Maletz, 2000

Remarks. While for Dumitrica et al. (2000), the family Rotasphaeridae is a junior synonym of Secuicollactidae, we follow here the opinion of Jones \& Noble (2006) and treat Secuicollactidae as the junior synonym of Rotasphaeridae because the former was introduced into the literature only informally.

\section{Genus Diparvapila MacDonald, 1998}

Type species. Diparvapila hicocki MacDonald, 1998.

\section{?Diparvapila $\mathrm{sp}$.}

(P1. 1, fig. 1)

Material. One specimen.

Dimensions (in $\mu \mathrm{m}$ ). Cortical shell diameter: 116; medullary shell diameter: 61; primary spine length: at least 48-50.

Remarks. The specimen is poorly preserved; however, a medullary shell is observed, which may indicate that this is a specimen of Diparvapila. Its medullary shell is a bit larger than that reported for $D$. larseni MacDonald, 1998, although the conical shape and size of spines are comparable. However, only two primary spines are preserved, probably not intact; the others seem to be broken; pores are not visible, thus preventing species-level identification.

\section{Genus Secuicollacta Nazarov \& Ormiston, 1984; emend. MacDonald, 1998}

Type species. Secuicollacta cassa Nazarov \& Ormiston, 1984.

Remarks. Won et al. established the genus Parasecuicollacta in 2002 based on a lumpy surface with ragged elements and short and conical primary spines, while Secuicollacta exhibits a smooth surface and clearly visible primary and secondary rods. We follow 


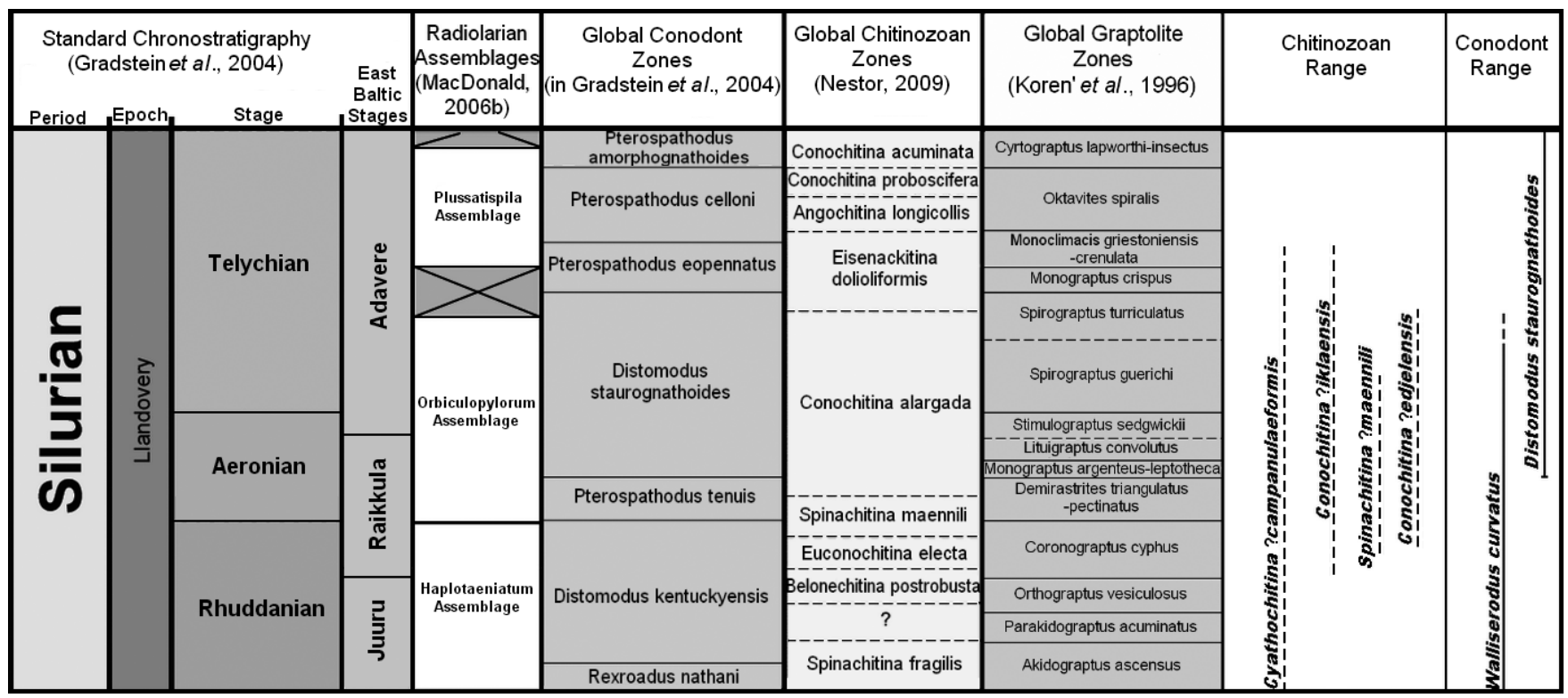

Fig. 3. Correlation chart of Early Silurian standard and east Baltic stratigraphic scales and radiolarian, conodont, chitinozoan and graptolite zonations. This figure also displays the range of the recovered conodonts and chitinozoans.

here the opinion of Jones \& Noble (2006) and consider Parasecuicollacta as a junior synonym of Secuicollacta.

Secuicollacta bipola (Won, Blodgett \& Nestor, 2002)

(Pl. 1, figs 2?, 3)

2002 Parasecuicollacta bipola Won, Blodgett \& Nestor: 953; figs 3.1-3.6, 3.14-3.17.

2014 Secuicollacta bipola (Won, Blodgett \& Nestor, 2002); Tetard et al.: fig. 3.1.

Material. Four specimens.

Dimensions (in $\mu \mathrm{m}$ ). Shell diameter: 95-111; primary spines length: up to $52-60$.

Occurrence. Middle Aeronian (sample MT18), Chalonnes-surLoire section, France (this study); lower Telychian, Road River Formation, Tatonduk River area, east-central Alaska (Won et al., 2002); lower to upper Telychian, Cape Phillips Formation, Cornwallis Island Nunavut, Canadian Arctic (MacDonald, 2006b).

Remarks. Some of our specimens exhibit only one major spine, the other one being probably broken, as mentioned by Won et al. (2002). These specimens (e.g. P1. 1, fig. 2) are tentatively identified as Secuicollacta bipola, because of their poor preservation.

Secuicollacta hexactinia (Won, Blodgett \& Nestor, 2002)

$$
\text { (Pl. 1, figs 4-8) }
$$

1998 Secuicollacta spp. Noble, Braun \& McClellan: fig. 6.7 (only).

2002 Parasecuicollacta hexactinia Won, Blodgett \& Nestor: 955; figs $3.7-3.11,3.13$.
2007 Secuicollacta hexactinia (Won, Blodgett \& Nestor); Siveter et al:: pl. 2, fig. 6.

2014 Secuicollacta hexactinia (Won, Blodgett \& Nestor); Tetard et al.: fig. 3.2.

Material. Thirteen specimens.

Dimensions (in $\mu \mathrm{m}$ ). Shell diameter: 100-129; primary spines length: up to $40-65$.

Occurrence. Middle Aeronian (sample MT18), Chalonnes-surLoire section, France (this study); lower Telychian, Road River Formation, Tatonduk River area, east-central Alaska (Won et al., 2002); upper Sheinwoodian to lower Homerian, Wenlock Series of Herefordshire, England (Siveter et al., 2007).

Remarks. This species is easily distinguishable thanks to the octahedral arrangement of the primary spines. Won et al. (2002) indicate this species may be synonymous with $S$. teli MacDonald, 1998 which also has a similar spine arrangement, but since no SEM images showing external details were included by MacDonald, the species are left separate. The presence of byspines and the number, shape and arrangement of principal spines are in good agreement with the description of both species. Secuicollacta glaebosa MacDonald, 1998 differs by the lack of by-spines, a more bladed surface and sometimes more than 6 spines (MacDonald, 1998).

Secuicollacta sp. cf. S. multispinosa (Won, Blodgett \& Nestor, 2002)

(P1. 1, figs 9-11)

cf. 2002 Parasecuicollacta multispinosa Won, Blodgett \& Nestor: 955; figs 4.4-4.9. 


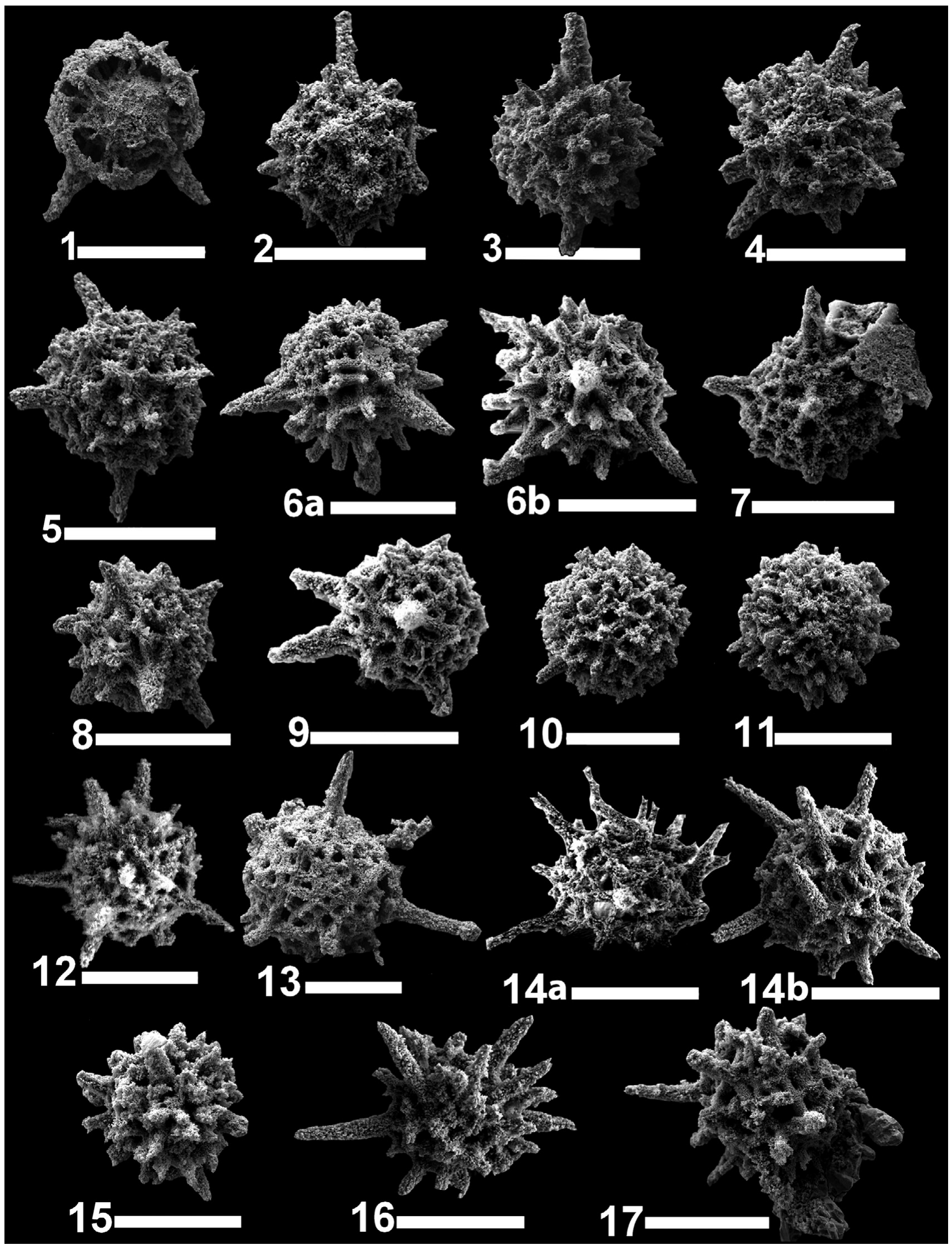


2014 Secuicollacta multispinosa (Won, Blodgett \& Nestor, 2002); Tetard et al.: fig. 3.3.

Material. Ten specimens.

Dimensions (in $\mu \mathrm{m}$ ). Shell diameter: 99-131; primary spines length: up to 58 .

Remarks. This species is very similar to $S$. hexactinia, but differs in having more than six primary spines, generally shorter and without any peculiar arrangement. Our specimens display a relatively small and thick spherical shell with a coarse latticed meshwork, without primary spine or with very short ones on some specimens. The identification is doubtful due to poor preservation. This species also shows primary units without primary spine or very small ones (a primary unit with five primary rods is visible in Pl. 1, fig. 10).

Secuicollacta parvitesta Won, Blodgett \& Nestor, 2002

(P1. 1, figs 12-13)

2002 Secuicollacta parvitesta Won, Blodgett \& Nestor: 949; figs 2.5-2.14, 2.18?, 2.19-2.21.

2006 Secuicollacta parvitesta Won, Blodgett \& Nestor, 2002; Jones \& Noble: 300 ; pl. 1, fig. 7.

2014 Secuicollacta parvitesta Won, Blodgett \& Nestor, 2002; Tetard et al.: fig. 3.4-3.5.

Material. Six specimens.

Dimensions (in $\mu \mathrm{m}$ ). Shell diameter: 118-160; primary spines length: up to 48-91.

Occurrence. Middle Aeronian (sample MT18), Chalonnes-surLoire section, France (this study); lower Telychian, Road River Formation, Tatonduk River area, east-central Alaska (Won et al., 2002); upper Sheinwoodian, Cape Phillips Formation, Nunavut, Arctic Canada (Jones \& Noble, 2006).

Remarks. Won et al. (2002) established two morphotypes for this species. The first one exhibits a smaller shell, more numerous byspines, fewer and larger pores, while the second one has a denser meshwork. Our specimens exhibit a size difference and may represent examples of both morphotypes; however, poor preservation precludes such detailed discrimination. According to Won et al. (2002), this species is very similar to $S$. alaskensis Won et al., 2002 which shows a thinner shell wall with a finer structure and shorter spines, and to $S$. tatondukensis exhibiting a less delicate meshwork and larger pores.

\section{Secuicollacta sp. cf. S. tatondukensis}

Won, Blodgett \& Nestor, 2002

(P1. 1, fig. 14) cf. 2002 Secuicollacta tatondukensis Won, Blodgett \& Nestor: 951; figs 1.14-1.20, 2.1-2.4, 6.5a, b.

Material. Two specimens.

Dimensions (in $\mu \mathrm{m}$ ). Shell diameter: 116-122; primary spines length: up to 64-72.

Remarks. Our specimens are similar to $S$. tatondukensis but with uncertainty due to poor preservation. They are also similar to $S$. parvitesta Morphotype 1, but differ in having more major spines, fewer by-spines and larger pores.

\section{Secuicollacta spp.}

(P1. 1, figs 15-17)

Material. Three specimens.

Description. Our specimens show a small spherical shell. Spines are numerous and large, making the meshwork barely visible, but it seems to be composed of straight rods. Primary units are recognizable; major spines appear to be the primary spines of primary units. These spines are larger and longer than by-spine-like spines.

Dimensions (in $\mu \mathrm{m}$ ). Shell diameter: 92-108; primary spines length: up to $62-71$.

Remarks. Our specimens exhibit numerous outer spines which appear to be broken, and typical large and straight primary rods. Plate 1, figure 17, is similar to Secuicollacta sp. in Won et al. (2002) in having straight primary rods. This specimen is also similar to S. parvitesta, but differs in having more numerous and shorter outer spines, and a meshwork consisting principally of straight primary rods.

Order Spumellaria Ehrenberg, 1875; emend. Riedel, 1967 Family Haplotaeniatidae Won, Blodgett \& Nestor, 2002; emend. Maletz, 2011

Genus Haplotaeniatum Nazarov \& Ormiston, 1993

Type species. Haplotaeniatum labyrintheum Nazarov \& Ormiston, 1993.

Remarks. This genus is characterized by a large spherical skeleton, containing a spirally arranged meshwork throughout most of the shell that consists of a succession of whorls and thus exhibits a three-dimensional spongy structure.

Haplotaeniatum aperturatum Noble, Braun \& McClellan, 1998 (Pl. 2, fig. 1)

1998 Haplotaeniatum? aperturatum Noble, Braun \& McClellan: 721; fig. 4.6 .

Explanation of Plate 1. fig. 1.?Diparvapila sp. (MT18). fig. 2.?Secuicollacta bipola Won et al., 2002 (MT18). fig. 3. Secuicollacta bipola Won et al., 2002 (MT18). figs 4-8. Secuicollacta hexactinia Won et al., 2002 (MT18). figs 9-11. Secuicollacta sp. cf. S. multispinosa Won et al., 2002 (MT18). fig. 12-13. Secuicollacta parvitesta Won et al., 2002 (MT18). fig. 14. Secuicollacta sp. cf. S. tatondukensis Won et al., 2002 (MT18). figs 15-17. Secuicollacta spp. (MT18). Scale bar $100 \mu \mathrm{m}$. 


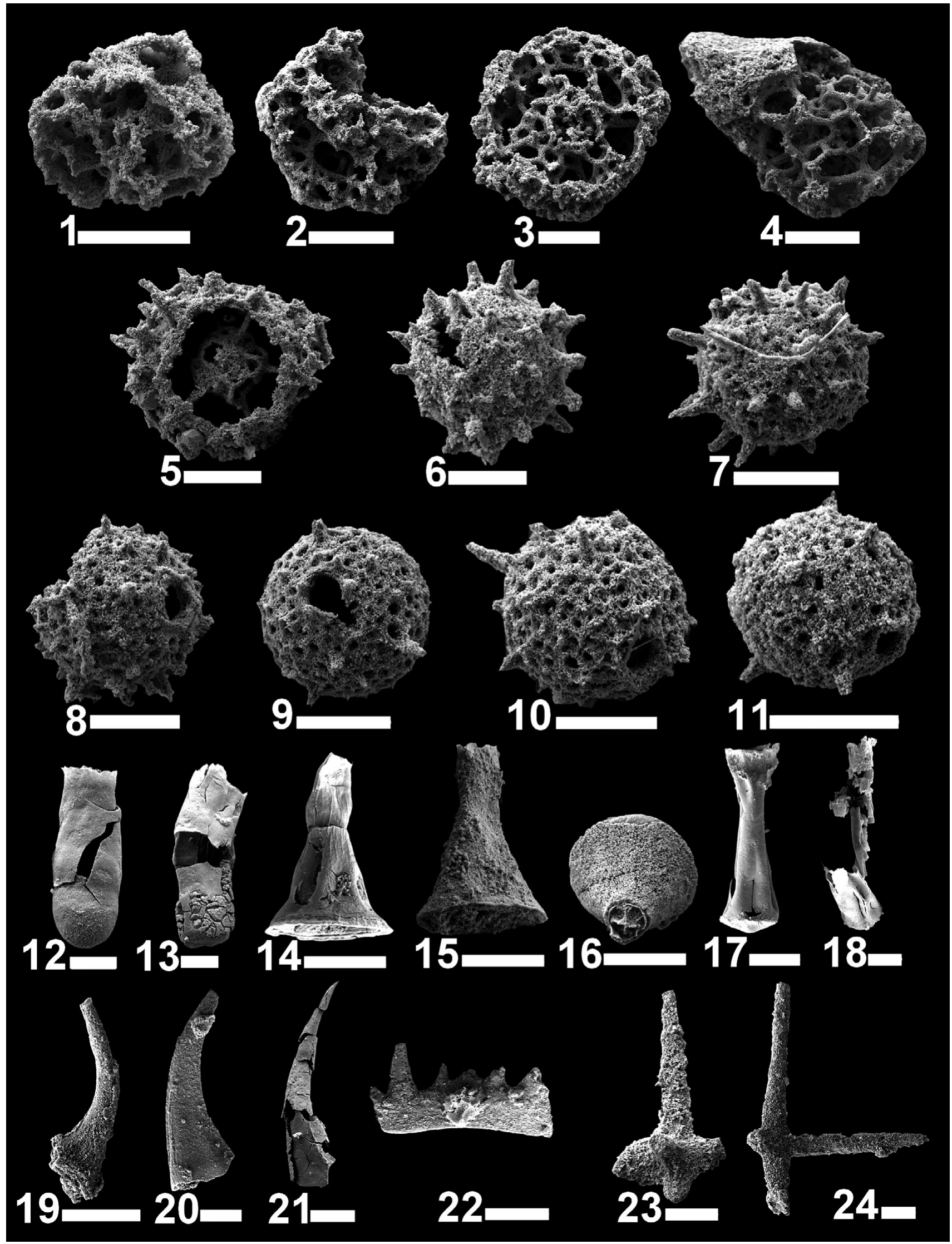


2002 Haplotaeniatum aperturatum Noble, Braun \& McClellan; Won et al.: 961; figs 5.11-5.13.

2005 Haplotaeniatum aperturatum Noble, Braun \& McClellan; Umeda \& Suzuki: 91; pl. 2 figs 3, 4.

2014 Haplotaeniatum aperturatum Noble, Braun \& McClellan; Tetard et al.: fig. 3.6.

Material. One specimen.

Occurrence. Upper Rhuddanian, Garden Pass, Northern Adobe Range, Nevada (Noble et al., 1998); middle Aeronian, Kallholn Formation, Siljan district, Sweden (Umeda \& Suzuki, 2005); middle Aeronian (sample MT18), Chalonnes-sur-Loire section, France (this study); lower Telychian, Road River Formation, Tatonduk River area, east-central Alaska (Won et al., 2002).

Genus Orbiculopylorum Noble, Braun \& McClellan, 1998

Type species. Orbiculopylorum marginatum Noble, Braun \& McClellan, 1998.

?Orbiculopylorum adobensis Noble, Braun \& McClellan, 1998 (Pl. 2, figs 2-4; Pl. 3, figs 1-2)

?1997 Cessipylorum? sp. B Noble, Ketner \& McClellan: 220; pl. 1, figs 9-10.

?1998 Orbiculopylorum adobensis Noble, Braun \& McClellan: 721; fig. 4.3, fig. 6.5 .

?2005 Orbiculopylorum adobensis Noble, Braun \& McClellan; Umeda \& Suzuki: 91; pl. 2 fig. 5.

Material. Five specimens.

Dimensions (in $\mu \mathrm{m}$ ). Outermost shell diameter: $225-326$.

Remarks. This species was first assigned to the genus Orbiculopylorum by Noble et al. (1998) based on a less dense meshwork interstitial to the medullary and cortical areas. It was reassigned to the genus Haplotaeniatum by Won et al. (2002) because the separation between cortical and medullary areas is not as clear in this species as it is in other species of Orbiculopylorum. However, the species identified as $H$. adobensis by Won et al. (2002) was synonymized with H. fissura by MacDonald (2006a) and considered distinct from $O$. adobensis. Our specimens are assigned to ?O. adobensis based on the features listed above, but doubts remain because we were not able to observe the pylome.

Orbiculopylorum granti MacDonald, 2006

(P1. 3, fig. 4)

2006 a Orbiculopylorum granti MacDonald: 29; figs 2.3, 2.5, 2.8, $6.1,6.2,6.5,6.6$.
Material. One specimen.

Dimensions (in $\mu \mathrm{m}$ ). Principal cortical shell diameter: 305 ('secondary' cortical shell diameter: 415); inner meshwork diameter: 135.

Occurrence. Uppermost Rhuddanian, lower Aeronian, Cape Phillips Formation, Cornwallis Island Nunavut, Canadian Arctic (MacDonald, 2006a); middle Aeronian (sample MT20), Chalonnes-sur-Loire section, France (this study).

Orbiculopylorum marginatum Noble, Braun \& McClellan, 1998 (Pl. 2, figs 5-8)

1997 Cessipylorum? sp. A Noble, Ketner \& McClellan: 220; pl. 1 , figs $11,12$.

1998 Orbiculopylorum marginatum Noble, Braun \& McClellan: 719; fig. 4.1.

2002 Orbiculopylorum marginatum Noble, Braun \& McClellan; Won et al.: 952; figs 5.18-5.20.

2005 Orbiculopylorum marginatum Noble, Braun \& McClellan; Umeda \& Suzuki: 91; pl. 2 figs 6, 7.

2014 Orbiculopylorum marginatum Noble, Braun \& McClellan; Tetard et al.: fig. 3.7.

Material. Fifteen specimens.

Dimensions (in $\mu \mathrm{m}$ ). Cortical shell diameter: 166-236; medullary shell diameter: 82-99.

Occurrence. Upper Rhuddanian, Garden Pass, Northern Adobe Range, Nevada (Noble et al., 1998); middle Aeronian, Kallholn Formation, Siljan district, Sweden (Umeda \& Suzuki, 2005); middle Aeronian (sample MT18), Chalonnes-sur-Loire section, France (this study); lower Telychian, Road River Formation, Tatonduk River area, east-central Alaska (Won et al., 2002).

Orbiculopylorum splendens Noble, Braun \& McClellan, 1998 (P1. 2, figs 9-11)

1998 Orbiculopylorum splendens Noble, Braun \& McClellan: 720; fig. 4.2.

2014 Orbiculopylorum splendens Noble, Braun \& McClellan; Tetard et al.: fig. 3.8 .

Material. Eight specimens.

Dimensions (in $\mu \mathrm{m}$ ). Cortical shell diameter: 170-193.

Occurrence. Upper Rhuddanian, Northern Adobe Range, Nevada (Noble et al., 1998); middle Aeronian (sample MT18), Chalonnessur-Loire section, France (this study).

Explanation of Plate 2. fig. 1. Haplotaeniatum aperturatum Noble et al., 1998 (MT18). figs 2-4.?Orbiculopylorum adobensis Noble et al., 1998: 3, 4 (MT8); 2 (MT19). figs 5-8. Orbiculopylorum marginatum Noble et al., 1998 (MT18). figs 9-11. Orbiculopylorum splendens Noble et al., 1998 (MT18). fig. 12. Conochitina ?iklaensis Nestor, 1980 (MT18). fig. 13. Conochitina ?edjelensis Taugourdeau, 1963 (MT18). figs 14-16. Cyathochitina ?campanulaeformis Eisenack, 1931 (MT18). figs 17-18. Spinachitina ?maennili Nestor, 1980 (MT18). fig. 19. Distomodus staurognathoides Walliser, 1964 (MT18). figs 20-21. Walliserodus curvatus Branson \& Branson, 1947 (MT18). fig. 22. Conodont S-element. figs 23-24. Hexactinellid megascleres incertae sedis (MT18). Scale bar $50 \mu \mathrm{m}$ for figs $12-13,17-18 ; 100 \mu \mathrm{m}$ for the rest. 


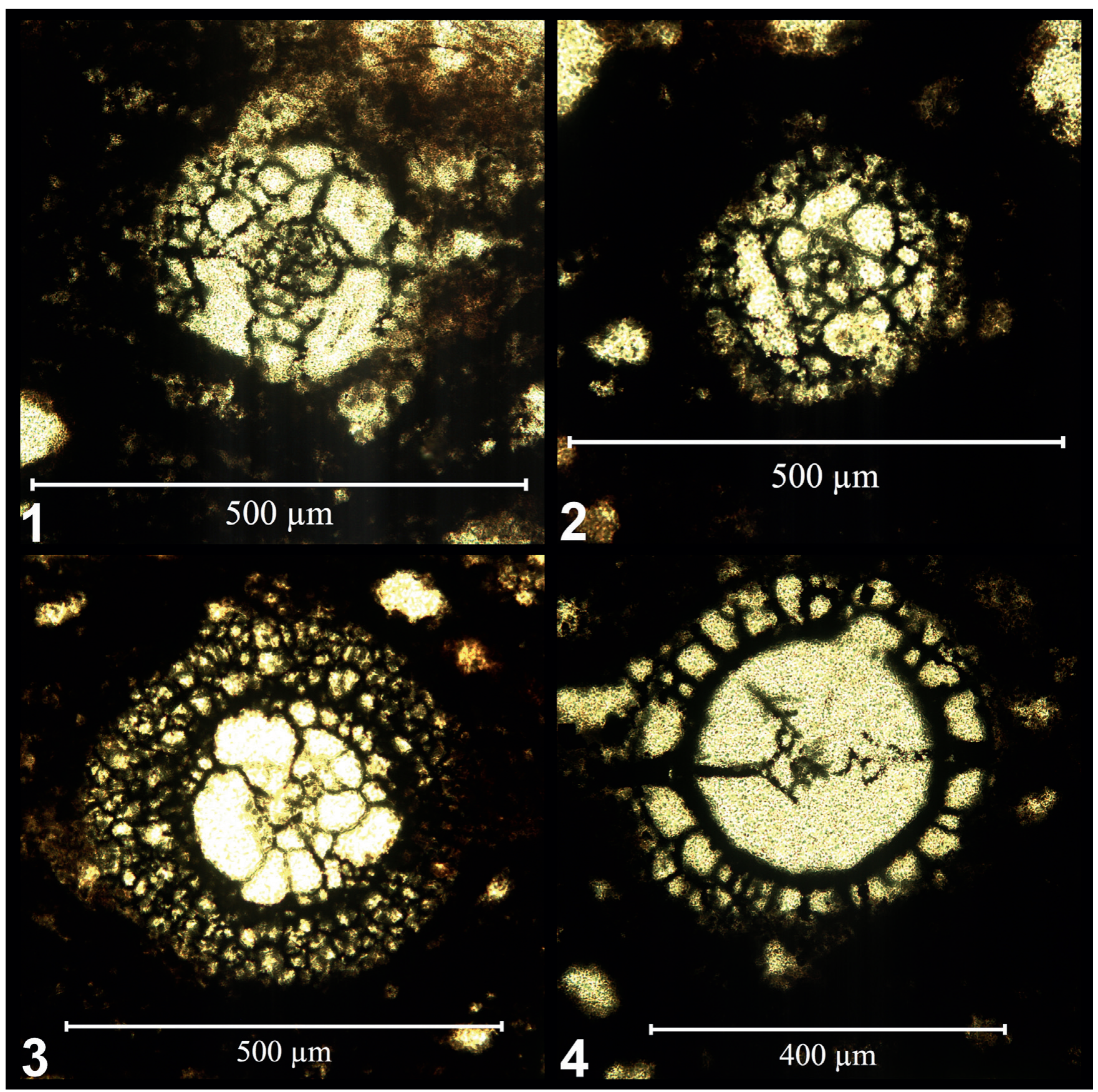

Explanation of Plate 3. figs 1-2. ?Orbiculopylorum adobensis Noble et al., 1998 (MT8). fig. 3. Haplotaeniatid gen. et sp. indet. (MT8). fig. 4. Orbiculopylorum granti MacDonald, 2006 (MT20).

Remarks. This species differs from $O$. marginatum in possessing less numerous and larger spines on its cortical shell (c. 8 per hemisphere, but $c .15$ in $O$. marginatum). Intermediate forms can be found.

Haplotaeniatid gen. et sp. indet.

$$
\text { (P1. 3, fig. 3) }
$$

Material. One specimen.

Dimensions (in $\mu \mathrm{m}$ ). Cortical shell diameter: 450 .
Remarks. Observed only in thin section, this specimen is characterized by a very loose inner meshwork, while the outer part is, on the contrary, very dense.

\section{DISCUSSION}

Integrated biostratigraphy and Radiolarian age ranges

The studied sequence at Chalonnes-sur-Loire was previously dated by abundant graptolites collected and identified by Piçarra et al. (2009). Based on their biostratigraphical assignment 


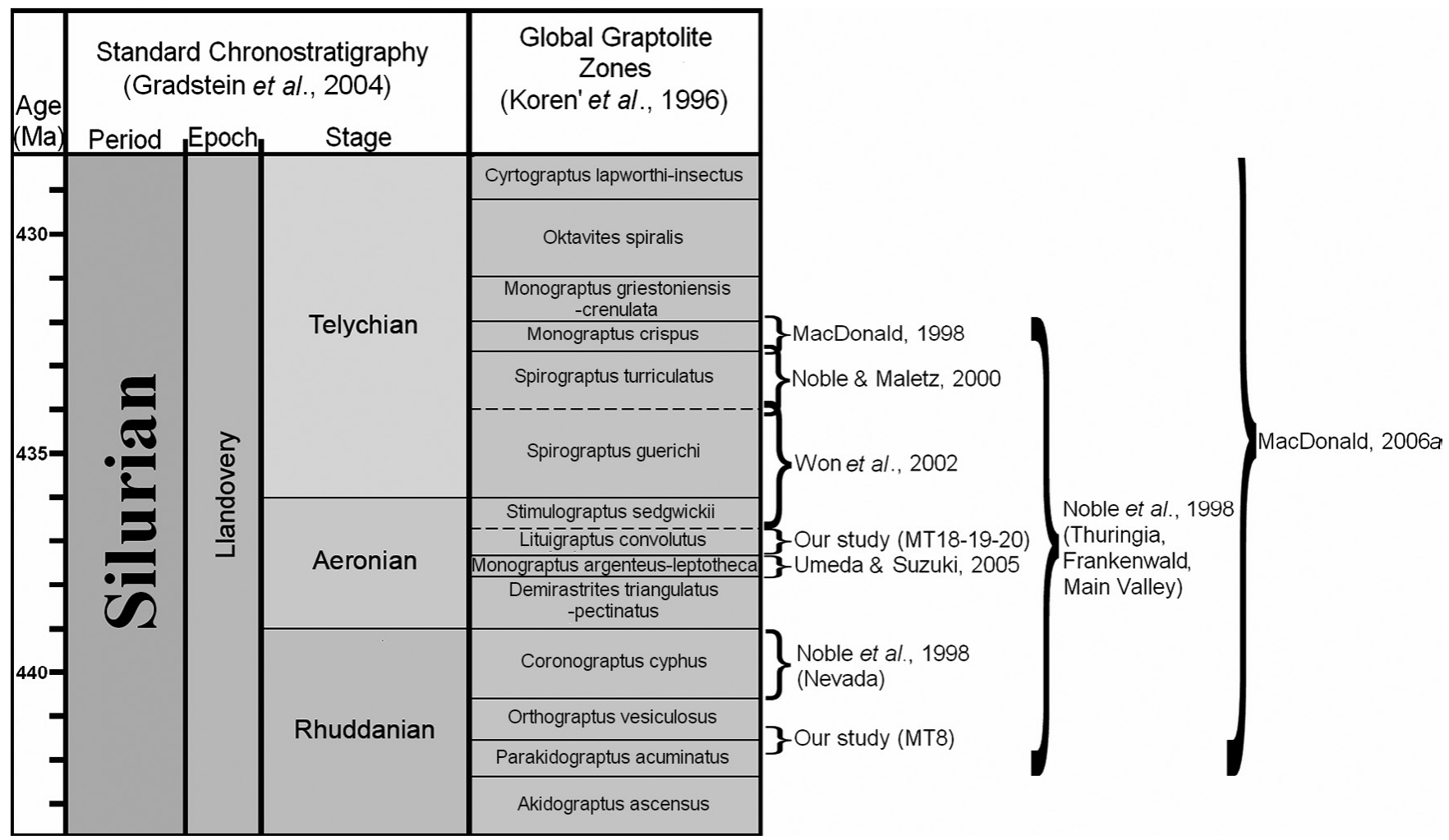

Fig. 4. Chronostratigraphic assignment of all known Llandovery radiolarian faunas in the literature including those discussed in our study.

(compare with their fig. 3), samples MT18, MT19 and MT20 can be assigned to the middle Aeronian (Lituigraptus convolutus graptolite biozone); in the same way, our sample MT8 can be assigned to the lower Rhuddanian (see Fig. 2). The common age range of conodonts and chitinozoans recovered from sample MT18 is in good agreement with the more accurate age provided by graptolites (see Fig. 3).

Silurian radiolarian biostratigraphy has made significant progress over the last 20 years, with the Llandovery being initially characterized by a single zone (Nazarov \& Ormiston, 1993), but subdivided later into three (MacDonald, 2006b; see Fig. 3). Sample MT18 contains numerous Orbiculopylorum specimens and it may be assigned to the Orbiculopylorum assemblage of MacDonald's biozonation (2006b), which is an informal taxon range zone whose base and top are respectively defined by the first and last occurrence of the genus Orbiculopylorum. In the Arctic sections studied by MacDonald (2006a, 2006b), the Orbiculopylorum assemblage was recovered from the lowermost Aeronian Campograptus curtus through mid-Telychian Spirograptus turriculatus Arctic graptolite zones. Orbiculopylorum was not found in material older than Aeronian in the Arctic (MacDonald 2006b).

Based on their occurrences in our section, the stratigraphic range of several secuicollactid and haplotaeniatid species can be extended. Thus, for species Secuicollacta bipola, S. hexactinia and $S$. parvitesta, for which the oldest previously known level was the lower Telychian (Won et al., 2002), their age range can be now extended down to the middle Aeronian. Concerning the haplotaeniatid species Orbiculopylorum granti, known previously from the lower Aeronian (MacDonald, 2006a), its age range is now extended up to the middle Aeronian. The same holds true for species O. splendens, previously known only from the upper Rhuddanian (Noble et al., 1998).

\section{Similarity to coeval radiolarian assemblages}

Figure 4 shows the age calibration of all known Llandovery radiolarian assemblages. Those described by Noble \& Maletz (2000) and MacDonald $(1998,2004)$ will not be considered in the following discussion, as their age is younger than the age of our fauna. The assemblage described by MacDonald (2006a) will not be considered either because it deals only with the family Haplotaeniatidae and not with the entire assemblage, and because the highly dissimilar preservation between well-preserved limestone and moderately preserved chert samples makes it difficult to make any meaningful comparisons of taxonomic composition.

The Alaskan assemblage (Fig. 5a) described by Won et al. (2002) shares 10 of its 17 species in common with the assemblage described by Noble et al. $(1997,1998)$ from Nevada, which contains 19 species (see Won et al. [2002] for a detailed comparison). Our assemblage shares at least 5 (and possibly 8) species in common with the Alaskan fauna (Secuicollacta bipola, S. hexactinia, S. parvitesta, Haplotaeniatum aperturatum, Orbiculopylorum marginatum, Secuicollacta sp. cf. S. multispinosa, Secuicollacta sp. cf. S. tatondukensis and ?O. adobensis). The Armorican assemblage also shares several species with the Nevadan fauna described by Noble et al. (1998), such as several secuicollactids (i.e. Secuicollacta hexactinia and S. multispinosa) and haplotaeniatids such as Haplotaeniatum aperturatum, Orbiculopylorum 


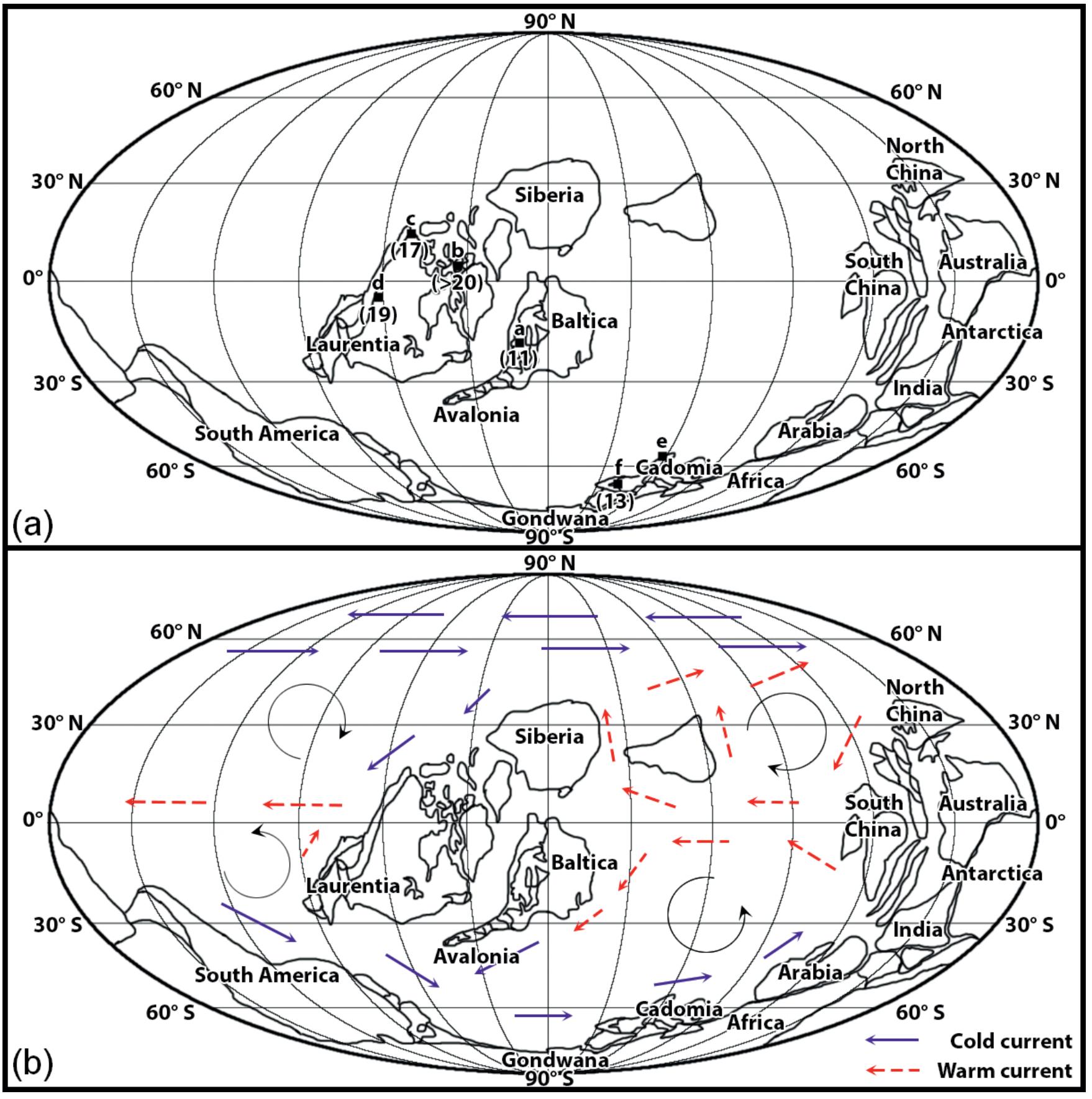

Fig. 5. (a) Palaeogeographical distribution of nearly all known Llandovery radiolarian localities. a - Dalarna, Sweden (Umeda \& Suzuki, 2005). b - Arctic Canada (MacDonald, 1998, 2004, 2006a). c - Alaska (Won et al., 2002). d - Nevada (Noble et al., 1997, 1998). e - Thuringia (Noble et al., 1998). f - Armorican Massif (Tetard et al., 2014). Numbers in brackets indicate the diversity of recorded species. (b) Global oceanic circulation during the lower Silurian (after Ziegler et al., 1977; Armstrong et al., 2009; Servais et al., 2014).

adobensis, O. marginatum, $O$. splendens and possibly $O$. granti. The Swedish fauna described by Umeda \& Suzuki (2005) contains three species (Haplotaeniatum aperturatum, Orbiculopylorym adobensis and $O$. marginatum) which are also present in the assemblages listed above.
Palaeogeographical distribution and palaeoceanographic scenarios

As discussed above, our assemblage from the Armorican Massif shares many common species with assemblages known from palaeogeographically widely dispersed areas in the lower Silurian, 
such as the Alaskan assemblage of Won et al. (2002), the Nevadan faunas of Noble et al. $(1997,1998)$ and the Swedish assemblage of Umeda \& Suzuki (2005). Several hypotheses detailed hereafter can possibly explain this global pattern of distribution for the Silurian and they may be responsible for the relative similarities between the equatorial and peripolar assemblages.

The incursion of tropical radiolarians into polar areas is not rare in modern oceans (Bjørklund et al., 2012), some of them being brought into high latitudes by regular pulses of warm water masses originated from the tropical realm. Figure $5 \mathrm{~b}$ illustrates a schematic map of global oceanic circulation during the Silurian, reconstructed after Ziegler et al. (1977), Armstrong et al. (2009) and Servais et al. (2014). It displays warm currents circulating towards the south, with western, central and eastern components. The western component is part of a west-Laurentia gyre that drives warm water away from Laurentia and drags plankton along southern Africa into high latitudes, whereas the central and eastern components circulate along the Baltica and Avalonia land masses, within the east Baltica gyre. Thus, planktic populations living in these currents could have been shifted from an equatorial into an austral position and be deposited into the Armorican and Thuringian basins.

Another important factor to take into account is the possible discrepancy between biocoenosis (living assemblage), thanatocoenosis (death assemblage) and taphocoenosis (fossil assemblage) (De Wever et al., 1994). Indeed, these planktic micro-organisms are considerably dependent on the oceanic currents (Bjørklund et al., 2012) and thus skeletons of radiolarians could be possibly transported over long distances even after their death. However, it is usually accepted that the lateral transport of radiolarian shells along long distances is limited. Indeed, the principal transport component is considered to be the sinking through aggregates and fecal pellets (De Wever et al., 1994; Lazarus, 2005). Thus the transport of micro-organisms is very restricted and the presence of foreign taxa in unusual latitudes (e.g. cold-water radiolarians into low latitudes, or reverse) probably shows the tolerance of this species (Lazarus, 2005).

\section{CONCLUSION}

The 'Chalonnes-sur-Loire' section consists essentially of Llandovery (Rhuddanian to Aeronian) black chert alternating with black shale that is rich in organic matter and pyrite and was deposited in an outer offshore environment, probably along a continental slope located on an intermediate-high latitudinal Gondwanan margin. This outcrop produced numerous graptolites and radiolarians, and an assemblage consisting of 13 species is described herein. Based on the composition of our assemblage in the best preserved sample (MT18), the upper part of the section was assigned to the Orbiculopylorum assemblage, which ranges from the base of the Aeronian to lower Telychian in the Arctic where it was originally defined. In the 'Chalonnes-sur-Loire' section, the Orbiculopylorum assemblage is definitively recognized in the middle Aeronian Lituigraptus convolutus graptolite zone, but may extend lower into the middle Rhuddanian, depending on whether specimens identified as ?Orboculopylorum adobensis are, in fact, this species. Comparison with other known lower Silurian assemblages, known essentially from tropical regions, reveals many similarities with our assemblage, which argues for a wide biogeographical dispersal of lower Silurian radiolarian plankton.

\section{ACKNOWLEDGEMENTS}

Laurence Debeauvais helped with laboratory processing of cherts, Sylvie Regnier with thin-section preparation, Philippe Recourt with the SEM, Sandra Ventalon with the RAMAN. Thanks to Thjis Vandenbroucke for discussion on chitinozoan identifications. Constructive remarks by Toshiyuki Kurihara and the handling editor (Claire Allen) improved the initial manuscript. The University Lille 1 is acknowledged for sponsoring a visiting professorship to Paula Noble.

\section{Manuscript received 1 May 2014 \\ Manuscript accepted 1 May 2014 \\ Scientific editing by Claire Allen}

\section{REFERENCES}

Armstrong, H.A., Baldini, J.U.L., Challands, T.J., Groecke, D.R. \& Owen, A.W. 2009. Response of the Inter-tropical Convergence Zone to Southern Hemisphere cooling during Upper Ordovician glaciation. Palaeogeogragraphy Palaeoclimatology Palaeoecology, 284: 227-236.

Ballèvre, M., Bosse, V., Ducassou, C. \& Pitra, P. 2009. Palaeozoic history of the Armorican Massif: Models for the tectonic evolution of the suture zones. Comptes Rendus Geoscience, 341: 174-201.

Bjørklund, K.R., Kruglikova, S.B. \& Anderson, O.R. 2012. Modern incursions of tropical Radiolaria into the Arctic Ocean. Journal of Micropalaeontology, 31: 139-158.

Butcher, A. 2009. Early Llandovery Chitinozoans from Jordan. Palaeontology, 52: 593-629.

Dabard, M.P. 2000. Petrogenesis of graphitic cherts in the Armorican segment of the Cadomian orogenic belt (NW France). Sedimentology, 47: 787-800.

Danelian, T., Noble, P.J., Pouille, L. \& Maletz, J. 2013. Palaeogeographic distribution of Ordovician Radiolarian occurrences: patterns, significance and limitations. In Harper, D.A.T. \& Servais, T. (Eds), Early Palaeozoic Palaeobiogeography and Palaeogeography. Geological Society, London, Memoirs, 38: 407-413.

De Wever, P., Azema, J. \& Fourcade, E. 1994. Radiolarians and radiolarites - primary production, diagenesis and paleogeography. Bulletin Des Centres De Recherches Exploration-Production Elf Aquitaine, 18: 315-379.

Dumitrica, P., Caridroit, M. \& De Wever, P. 2000. Archaeospicularia, ordre nouveau de radiolaires: Une nouvelle étape pour la classification des radiolaires du Paléozoïque inférieur. Comptes Rendus de l'Académie des Sciences, 330: 563-569.

Ehrenberg, C.G. 1838. Über der Bildung der Kreidefelsen und des Kreidemergels druch unsichtbare Organismen. Abhandlungen der Königlichen Akademie des Wissenschaften zu Berlin, 1838: 59- 147.

Ehrenberg, C.G. 1875. Fortsetzung der mikrogeologischen Studien als Gesammt-Uebersichtder mikroskopischen Palaontologie gleichartig analysirter Gebirgsarten der Erde, mit specieller Rucksicht auf den Polycystinen-Mergel von Barbados. Abhandlungen Konigliche Akademie der Wissenschaften zu Berlin, 1875: 1-225.

Ghavidel-Syooki, M. 2006. Chitinozoan Biostratigraphy and Palaeogeography of Silurian Strata (Niur Formation) at Eastern Alborz Range (Kopet-Dagh Region) Northeastern Iran. Jounal of Science (University of Tehran), 32: 127-146.

Ghavidel-Syooki, M. \& Vecoli, M. 2007. Latest Ordovician-early Silurian chitinozoans from the eastern Alborz Mountain Range, Kopet-Dagh region, northeastern Iran: biostratigraphy and palaeobiogeography. Review of Palaeobotany and Palynology, 145: 173-192. 
Gradstein, F., Ogg, J. \& Smith, A. 2004. A Geologic Time Scale 2004. Cambridge University Press, Cambridge, 589pp.

Hints, O., Killing, M., Männik, P. \& Nestor, V. 2006. Frequency patterns of chitinozoans, scolecodonts, and conodonts in the upper Llandovery and lower Wenlock of the Paatsalu core, western Estonia. Proceedings of the Estonian Academy of Sciences, Geology, 55: 128-155.

Jones, M.K. \& Noble, P.J. 2006. Sheinwoodian (Uppermost Lower Silurian) radiolaria from the Cape Phillips Formation, Nunavut, Canada. Micropaleontology, 52: 289-315.

Kleffner, M.A. 1987. Conodonts of the Estill Shale and Bisher Formation (Silurian, Southern Ohio): biostratigraphy and Distribution. Ohio Journal of Science, 87: 78-89.

Koren, T.N., Lenz, A.C., Loydell, D.K., Melchin, M.J., Storch, P. \& Teller, L. 1996. Generalized graptolite zonal sequence defining Silurian time intervals for paleogeographic studies. Lethaia, 29: $59-60$.

Korovnikov, I., Sennikov, N., Danelian, T., Obut, O. \& Pouille, L. 2013. The biostratigraphic and palaeoenvironmental significance of Lower Cambrian (Botomian) trilobites from the Ak-Kaya section of the Altai Mountains (southern Siberia, Russia). Annales de Paléontologie, 99: 79-89.

Kurihara, T. \& Sashida, K. 2000. Early Silurian (Llandoverian) radiolarians from the Ise area of the Hida 'Gaien' Belt, central Japan. Paleontological Research, 4: 147-162.

Lazarus, D. 2005. A brief review of Radiolarian research. Paläontologische Zeitschrift, 79: 183-200.

Loydell, D.K., Mannik, P. \& Nestor, V. 2003. Integrated biostratigraphy of the lower Silurian of the Aizpute-41 core, Latvia. Geological Magazine, 140: 205-229.

Loydell, D.K., Nestor, V. \& Mannik, P. 2010. Integrated biostratigraphy of the lower Silurian of the Kolka-54 core, Latvia. Geological Magazine, 147: 253-280.

MacDonald, E.W. 1998. Llandovery Secuicollactinae and Rotasphaeridae (Radiolaria) from the Cape Phillips Formation, Cornwallis Island, Arctic Canada. Journal of Paleontology, 72: 585-604.

MacDonald, E.W. 2004. Palaeoscenidiidae (Radiolaria) from the Lower Silurian of the Cape Phillips Formation, Cornwallis Island, Nunavut, Canada. Journal of Paleontology, 78: 257-274.

MacDonald, E.W. 2006a. Haplotaeniatumidae and Inaniguttidae (Radiolaria) from the Lower Silurian of the Cape Phillips Formation, Cornwallis Island, Nunavut, Canada. Journal of Paleontology, 80: 19-37.

MacDonald, E.W. 2006b. A preliminary radiolarian biozonation for the Lower Silurian of the Cape Phillips Formation, Nunavut, Canada. Canadian Journal of Earth Sciences, 43: 205-211.

Maletz, J. 2011. Radiolarian skeletal structures and biostratigraphy in the early Palaeozoic (Cambrian-Ordovician). Palaeoworld, 20: $116-133$.

Müller, J. 1858. Über die Thalassicollen, Polycystinen und Acanthometren des Mittelmeeres. Abhandlungen Konigliche Akademie Wissenschaften zu Berlin, 1858: 1-62.

Nazarov, B.B. \& Ormiston, A.R. 1984. Tentative system of Paleozoic Radiolaria. In Petrushevskaya, M.G. \& Stepanjants, S.D. (Eds), Morphology, Ecology and Evolution of Radiolaria. (Eurorad IV Symposium volume October 1984). Akademiia NAUK SSSR Ecologieskiya Instiytut, Leningrad, 64-87.
Nazarov, B.B. \& Ormiston, A.R. 1993. New biostratigraphically important Paleozoic Radiolaria of Eurasia and North America. Micropaleontology Special Publication, 6: 22-60.

Nestor, V. 2009. Chitinozoan diversity in the East Baltic Silurian. Estonian Journal of Earth Sciences, 58: 311-316.

Nestor, V. 2012. A summary and revision of the East Baltic Silurian chitinozoan biozonation. Estonian Journal of Earth Sciences, 61: 242-260.

Noble, P.J. 1994. Silurian radiolarian zonation for the Caballos Novaculite, Marathon Uplift, west Texas. Bulletins of American Paleontology, 106: $1-55$.

Noble, P.J. \& Aitchison, J. 2000. Early Paleozoic radiolarian biozonation. Geology, 28: 367-370.

Noble, P.J. \& Maletz, J. 2000. Radiolaria from the Telychian (Llandovery, Early Silurian) of Dalarna, Sweden. Micropaleontology, 46: 265-275.

Noble, P.J., Ketner, K.B. \& McClellan, W. 1997. Early Silurian radiolaria from northern Nevada, USA. Marine Micropaleontology, 30: 215-223.

Noble, P.J., Braun, A. \& McClellan, W. 1998. Haplotaeniatum faunas (Radiolaria) from the Llandoverian (Silurian) of Nevada and Germany. Neues Jahrbuch für Geologie und Paläontologie, Monatshefte, 12: 705-726.

Piçarra, J.M., Robardet, M. et al. 2002. The Ordovician-Silurian transition and the lower part of the Silurian (southeastern Armorican Massif, France). Comptes Rendus Geoscience, 334: 1177-1183.

Piçarra, J.M., Robardet, M., Oliveira, J.T., Paris, F. \& Lardeux, H. 2009. Graptolite faunas of the Llandovery 'phtanites' at Les Fresnaies (Chalonnes-sur-Loire, southeastern Armorican Massif): palaeontology and biostratigraphy. Bulletin of Geosciences, 84: 41-50.

Pouille, L., Obut, O., Danelian, T. \& Sennikov, N. 2011. Lower Cambrian (Botomian) polycystine Radiolaria from the Altai Mountains (southern Siberia, Russia). Comptes Rendus Palevol, 10: 627-633.

Riedel, W.R. 1967. Some new families of Radiolaria. Proceedings of the Geological Society of London, 1640: 148-149.

Servais, T., Danelian, T., Harper, D.A.T. \& Munnecke, A. 2014. Possible oceanic circulation patterns, surface water currents and upwelling zones in the Early Palaeozoic. GFF, 136: 229-233, http://dx.doi.org/10.1080/11035897.2013.876659

Siveter, D.J., Aitchison, D.C., Siveter, D.J. \& Sutton, M.D. 2007. The Radiolaria of the Herefordshire Konservat-Lagerstätte (Silurian), England. Journal of Micropalaeontology, 26: 87-95.

Tetard, M., Danelian, T., Ghienne, J.F. \& Dabard, M.P. 2014. A Lower Silurian (Aeronian) radiolarian assemblage from black cherts of the Armorican Massif (France). Comptes Rendus Palevol, 13, 483-488 http://dx.doi.org/10.1016/j.crpv.2014.01.001

Umeda, M. \& Suzuki, Y. 2005. Aeronian (Llandovery, Early Silurian) radiolarians from the Kallholn Formation in Siljan district, Sweden. Micropaleontology, 51: 83-91.

Won, M.Z., Blodgett, R.B. \& Nestor, V. 2002. Llandoverian (Early Silurian) radiolarians from the road river formation of east-central Alaska and the new family Haplotaeniatumidae. Journal of Paleontology, 76: 941-964.

Zhang, S.X. \& Barnes, C.R. 2002. A new Llandovery (Early Silurian) conodont biozonation and conodonts from the Becscie, Merrimack, and Gun River formations, Anticosti Island, Quebec. Journal of Paleontology, 76: 1-46.

Ziegler, A.M., Hansen, K.S., Johnson, M.E., Kelly, M.A., Scotese, C.R. \& Vandervoo, R. 1977. Silurian continental distributions, paleogeography, climatology, and biogeography. Tectonophysics, 40: 13-51. 